\title{
Psychologia mediów wobec terroryzmu samobójczego
}

\begin{abstract}
Media psychology towards suicide terrorism

This article is a conclusion of the considerations taken on psychology of media towards suicide terrorism. The phenomenon of suicide has been the subject of interest recently relatively, despite the fact that the mentioned act has been observed and described since antiquity ${ }^{1}$. On the psychological level, suicide is an offense against the unconditional instinct of life and the supreme value of life. The XXIst century brings a lot of different threats as the environment and the whole word around us under go major, continuous transformations connected with the progress. This progress might be seen from various perspectives and concerns civilization, industry, science or technology ${ }^{2}$. In this article, I focus on terrorism as a major threat of the contemporary world and analyse the phenomenon from the historical and contemporary point of view.
\end{abstract}

Key words: media psychology, suicide

\section{Wprowadzenie}

Europa stoi obecnie przed największym zagrożeniem terrorystycznym obserwowanym w ostatniej dekadzie. Informacje dotyczące terroryzmu pojawiają się praktycznie na każdej platformie internetowej, w telewizji czy w radiu. Coraz

\footnotetext{
${ }^{1}$ B. Hołyst, Bezpieczeństwo jednostki, Warszawa 2014, s. 171-175.

${ }^{2}$ G. Kwiatkowska, A. Siudem, Człowiek w środowisku pracy, Lublin 2011, s. 4-11.
} 
częściej społeczeństwo obawia się aktów terrorystycznych, które jeszcze kilkanaście lat temu były raczej bagatelizowane przez obywateli. Można przypuszczać, że dla większości z nich nie zdarzały się w ich najbliższym otoczeniu. Ataki i zagrożenie terroryzmem według opinii społecznej nie były aż tak realne i zagrażające jak w chwili obecnej. Nie sposób nie wspomnieć o tzw. rewolucji cyfrowej, która sprawiła, że obywatele są na niespotykanym dotąd poziomie rozwoju technologicznego. Co ważne, pojawienie się mediów społecznościowych zmieniło zachowanie, interakcje, modus operandi i sposoby komunikacji zarówno obywateli, jak i grup terrorystycznych ${ }^{3}$. „Społeczeństwo 2.0 ” jest pochodną określenia pojęcia „sieć 2.0”, które określa nowoczesne oblicza Internetu. Podobnie jak inne kwestie w życiu społecznym - i ta platforma ciągle się zmienia i udoskonala. W związku z tym dochodzi do różnorodnych następstw, w tym tych negatywnych. Należy jednak pamiętać, że rozwój i wzrost możliwości, które za sobą niesie Internet, wiąże się z niebezpieczeństwem i wielowymiarowymi problemami, z którymi trudno poradzić sobie nawet najbardziej profesjonalnym i nowoczesnym instytucjom.

Nawet najbardziej modernistyczne programy profilaktyczne, prewencyjne nie są w stanie wychwycić treści w sposób natychmiastowy. Niestety niektóre z nich mogą być dla obywateli niewłaściwymi, a nawet niepożądanymi informacjami. Faktem jest to, że zdecydowanie trudno kontrolować wszystko to, co znajduje się w Internecie. Danych jest bardzo dużo, a ich przeznaczenie nie zawsze służy do pozytywnych aspektów. Otóż mogą być to informacje wykorzystane efektywnie dla budowania wspólnego bezpieczeństwa społeczeństw, ale także do niszczenia jego wewnętrznych więzi. Problem motywacji zachowań suicydalnych można rozpatrywać w szerokim znaczeniu. Jest to zróżnicowane ze względu na status społeczno-ekonomiczny, miejsce zamieszkania, wiek czy wcześniejsze doświadczenia. Niemniej jednak warto w każdej sytuacji wziąć pod uwagę takie kwestie, jak środowisko społeczne oraz środowisko rodzinne, które są podstawą funkcjonowania człowieka. W tym przypadku znaczącą rolę odgrywa osobowość, dojrzałość jednostki oraz jej system wartości. Wyzwaniem jest także umiejętność radzenia sobie w sytuacji trudnej oraz tolerancja na wyzwania dnia codziennego, jak również reakcje i sposoby radzenia sobie ze stresem. Motywacja związana $z$ tendencjami samobójczymi dotyczy siły postaw oraz mechanizmów obronnych oraz sytuacji, która wyzwoliła tendencje samobójcze ${ }^{4}$.

Realnie samobójstwa związane są z ubytkiem jakiegoś procentu populacji na skutek śmierci lub obniżenia potencjału sił społecznych na skutek zachowań suicydalnych. Terroryzm samobójczy jest interpretowany w taki sposób, iż śmierć

${ }^{3}$ https://www.europol.europa.eu/publications-documents/eu-internet-referral-unit-year-one-report-highlights [dostęp: 12.01.2018].

${ }_{4}^{4}$ M. Jarosz, Samobójstwa, Warszawa 1997, s. 55-98. 
sprawcy jest koniecznym warunkiem powodzenia konkretnej misji. Akt przemocy jest popełniony przez samoświadomą jednostkę, która aktywnie i w sposób zamierzony powoduje własną śmierć z zamiarem zniszczenia danego wcześniej określonego celu 5 . Psychologia mediów zajmuje się także kwestią uwarunkowań aktów autodestrukcyjnych, w tym zachowań samobójczych ${ }^{6}$.

Zachodzące we współczesnym świecie przemiany polityczne, technologiczne, gospodarcze, kulturowe czy światopoglądowe są ujmowane jako przejawy zachodzących w szerokiej perspektywie przeobrażeń. Zmierzają one do coraz większej współzależności jednostek, a także wielowymiarowej integracji . Rozwój i wykorzystanie technologii informacyjnych przyczynia się w znacznym stopniu do szybszych i skuteczniejszych przedsięwzięć w społeczeństwie. Nowoczesność jest dla wielu jednostek i organizacji poważnym wyzwaniem zarówno z racji procesu globalizacji, jak również z powodu pogłębiającego się problemu ekskluzji społecznej ${ }^{8}$. Problem samobójstw jest złożony - nie zawsze prowadzą one do samobójstwa dokonanego, czyli całkowitego unicestwienia jednostki. Samobójstwo jest zjawiskiem społecznym, które towarzyszy człowiekowi od najdawniejszych czasów, niekoniecznie jest ono aktem ostatecznym. Osoby, które charakteryzuje kryzys, trudności emocjonalne, zaburzenia osobowości i inne często wykorzystują szantaż, groźby czy zastraszenie do osiągnięcia swoich celów9 . Różnorodność sytuacji skłania do rozważań aspektów związanych z samobójstwem $\mathrm{z}$ wielu perspektyw, w tym: filozoficznej, psychologicznej, pedagogicznej, społecznej, politycznej czy prawnej ${ }^{10}$.

\section{Media a zagrożenia}

W cywilizacji XXI wieku coraz większe znaczenie dla ludzkości mają środki masowego przekazu. Wiadomość, która pojawia się w sieci, w ciągu kilku minut może dotrzeć nawet do najdalszych części świata. Rozpowszechnianie się jest procesem bardzo dynamicznym, trudniej jednak o wyhamowanie dostępu do negatywnych

${ }^{5}$ R.M. Martin, Should we try to preventsuicide, Ottawa 1979, s. 279-281.

${ }^{6}$ K.A. van Orden i in., The interpersonal theory of suicide, „Psychological Review” 2010, t. 117, s. $575-600$.

7 B. Hołyst, Wiktymologia, Warszawa 2011, s. 93.

${ }^{8}$ E.W. Pływaczewski, E.M. Guzik-Makaruk, D. Dajnowicz, Działania Wydziału Prawa Uniwersytetu w Białymstoku na rzecz przeciwdziałania wykluczenia społecznemu, [w:] Wybrane prawne kryminologiczne i medyczne aspekty wykluczenia społecznego, red. E.M. Guzik-Makaruk, E.W. Pływaczewski, Białystok 2016, s. 15-33.

9 Zob. K. Dymek-Balcerek, Patologia społeczna wśród dzieci i młodzieży - rzeczywistość lat dziewięćdziesiatych, Radom 1999.

${ }^{10}$ E. Ringel, Gdy życie traci sens. Rozważania o samobójstwie, Szczecin 1987, s. 57-98. 
informacji $\mathrm{w} \operatorname{sieci}^{11}$. Środki masowego przekazu często manipulują ludźmi, istnieje wiele teorii, które wykazują te tendencje, np. teoria magicznego pocisku (the magic bullet theory) lub teoria zastrzyku (injection theory), podskórnego wpływu (hipodermie theory). Pierwsze badania $\mathrm{z}$ lat trzydziestych XX wieku, dające początek tej teorii, wykazały znaczący wpływ kina na najmłodszych przedstawicieli społeczeństwa. Ważne $\mathrm{w}$ tej teorii jest jednak założenie, iż film (przekaz audiowizualny) jest porównywany do pocisku - wywiera wpływ na postawę odbiorcy, sposób odbierania i traktowania innych ludzi, relacje, styl zachowywania się, ubierania się, jak również wysławiania. Ta teoria określana jest także jako teoria wszechmocy mediów. Przekaz medialny z metaforyczną siłą pocisku działa na ludzkie zmysły, wywołując w człowieku skutki: bezpośrednie (dotyczy danej jednostki i jej najbliższego otoczenia), natychmiastowe (w tym samym czasie dociera do znaczącej liczby osób), jednakowe (przekazywana informacja jest identyczna). Media w tej teorii rozumiane są zatem jako wszechpotężne, dające ich dysponentom niemalże absolutną władzę ${ }^{12}$.

Media są narzędziem o ogromnym znaczeniu dla populacji, gdyż duża jej część ma dostęp do tychże platform. Ułatwia to możliwość komunikowania się z innymi osobami, a fakt ten wykorzystały ugrupowania terrorystyczne, a szczególnie terroryści, w tym samobójcy. Samobójstwo jest problemem wieloaspektowym, nie ma zazwyczaj jednej przyczyny. Osoba zazwyczaj planuje, wyobraża sobie kwestie związane z tym, że chce ze sobą skończyć, oraz to, w jaki sposób zrealizuje niniejsze zamierzenie. Jednakże warto zaznaczyć, że u osób zaangażowanych w działalność grup terrorystycznych sytuacja wygląda nieco inaczej. W związku z tym, że do samego końca muszą oni zachować pozory normalnego życia, owe zorganizowane działania uniemożliwiają lub znacznie utrudniają pracę organom ścigania.

Do przyczyn samobójstwa można zaliczyć między innymi: problemy rodzinne, złą sytuację finansową w najbliższym środowisku czy śmierć kogoś kochanego. Traumatyczne wydarzenia są w pewien sposób związane z pojawieniem się patologicznych sytuacji w życiu ludzkim - w szczególności takie kwestie, które dotykają jednostkę osobiście, np. rozstanie z przyjaciółmi, nacisk ze strony rówieśniczej czy tyranizowanie. Brak poprawnych kontaktów z najbliższym otoczeniem wpływa również na to, że człowiek w pewnych przypadkach nie czuje się akceptowany i potrzebny. Szczególnie trudne u młodych osób są sytuacje zerwania związku miłosnego czy niechciana ciąża, co jest przyczyną, która może doprowadzić do autodestrukcji. Ważną kwestią w życiu człowieka jest miejsce, w którym spędza bardzo dużo czasu - na początku jest nim szkoła - wysoki poziom wymagań w tejże

${ }_{11}$ M. Susułowska, P. Sztompka, Próba wyjaśnienia młodzieżowych zamachów samobójczych, „Psychologia Wychowawcza” 1987, nr 5, s. 34-43.

12 B. Hołyst, Suicydologia, Warszawa 2012, s. 105-220. 
placówce czy rozczarowanie wynikami w nauce wpływa na całokształt funkcjonowania jednostki. Do czynników powodujących kryzys suicydalny można zaliczyć np. poważną chorobę somatyczną czy zakażenie chorobą przenoszoną drogą płciową. Kolejnym ważnym elementem są kwestie ideologiczne, religijne czy kulturowe. Jeżeli człowiek nie do końca odnajduje się w społeczności, do której przynależy, i angażuje się w różnorodne aktywności, może czuć się odrzucony przez otoczenie.

Skutki zachowań samobójczych są również wielowymiarowe, według profesora Brunona Hołysta dotykają one od 11-20 osób w otoczeniu, w którym żyjemy (rodzina, znajomi, osoby znaczące, klasa, grupa akademicka, wspólnota kościoła itp. $)^{13}$.

Rys. 1. Skutki zachowań samobójczych

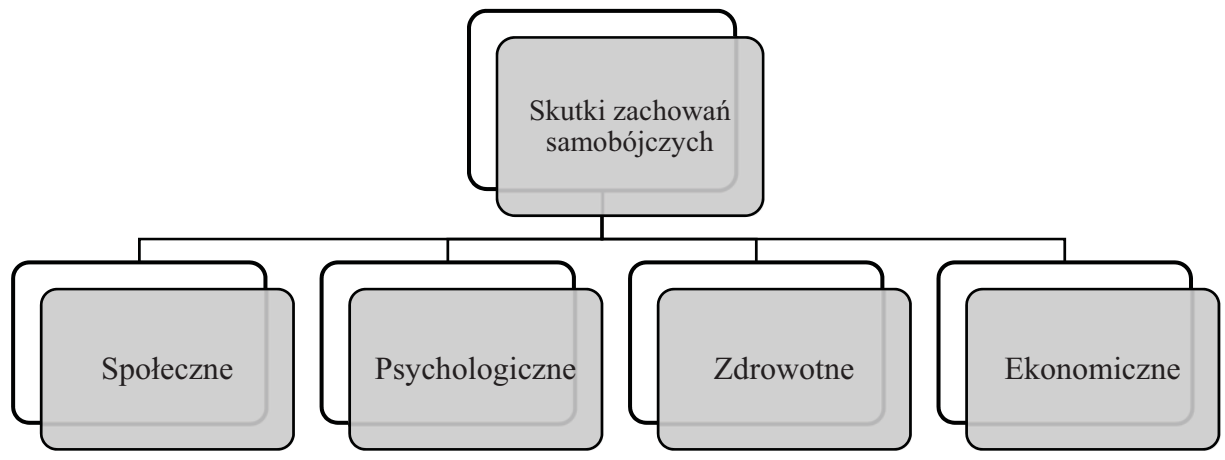

Źródło: Polskie Towarzystwo Suicydologiczne.

Zachowania samobójcze mają wiele negatywnych skutków związanych z funkcjonowaniem całego społeczeństwa ${ }^{14}$. Należą do nich skutki społeczne, psychologiczne, zdrowotne oraz ekonomiczne ${ }^{15}$. Każda $\mathrm{z}$ tych struktur jest jednakowo ważna, a wszystkie stanowią całość funkcjonowania danej zbiorowości. W sytuacji suicydalnej ważna jest odpowiednia pomoc, w tym wzmacnianie kompetencji służb pomocowych, uwrażliwienie opinii społecznej na niniejszą kwestię, wzmocnienie systemu pomocy dla osób z grup ryzyka czy promocja wsparcia specjalistycznego ${ }^{16}$.

${ }^{13}$ J. Komender, Zapobieganie próbom samobójczym podejmowanym przez dzieci i młodzież, [w:] Samobójstwo, red. B. Hołyst, M. Staniaszek, Warszawa-Łódź, 1995, s. 94-100.

${ }^{14} \mathrm{http}: / /$ suicydologia.org/.

15 B. Hołyst, op.cit., s. 255.

16 C. Cekiera, Zapobieganie samobójstwom. Poradnik dla nauczycieli i innych pracowników szkoły, Genewa-Warszawa 2003, s. 15-16. 


\section{Internet wobec terroryzmu}

Obecnie terroryzm jest używany jako synonim buntu, rebelii, powstania, walk ulicznych, zamachu stanu, partyzantki. Wówczas walka o cele polityczne toczy się z pomocą niezwykle przerażających środków. W polskiej literaturze można doszukać się już ponad 200 definicji terroryzmu ${ }^{17}$.

Internet stanowi platformę do wymiany różnorodnych poglądów, warto w tym momencie zaznaczyć, że jest on także wykorzystywany często $\mathrm{w}$ realnych sytuacjach znanych z okrucieństwa i terroru. Dla przykładu Adreas Brevik przed zamachem w Norwegii rozesłał do osób, które utożsamiały się z jego ideologią, wiadomości e-mail, w której informował o swoich planach - jego działalność była rozszerzona, miał on konta na portalach społecznościowych. Ponadto prowadził blogi, na których umieszczał informacje na temat swoich planów i realizacji zamierzeń. Publikowane przez niego posty i notatki docierały do wielu osób, a jego aktywność miała cechy związane z komunikacją, jak i działalnością propagandową. Ostatnie działania terrorystyczne i udaremnione ataki rzuciły światło na to, w jaki sposób Internet jest obecnie wykorzystywany przez terrorystów jako kluczowy element propagandy, rekrutowania, radykalizacji, koordynowania działań terrorystycznych i gloryfikowania ich okrucieństw. Szczególnie okrutny jest fakt, że terroryści korzystają z Internetu również w fazie ataku. Wiedząc o zakresie problemu, w dniu 12 marca 2015 r. Rada Unii Europejskiej do spraw Wymiaru Sprawiedliwości i Spraw Wewnętrznych (WSiSW) uzgodniła, że korzystając z usługi Europol „Check-the-Web” (CTW), Europol powinien utworzyć unijną jednostkę, która obejmowałaby następujące podstawowe zadania:

1. koordynowanie i dzielenie się z odpowiednimi partnerami zadaniami identyfikacji (oznaczaniem) treści terrorystycznych i brutalnych ekstremistów w Internecie;

2. szybka, sprawna i skuteczna realizacja i obsługa zgłoszeń w ścisłej współpracy z branżą;

3. wspieranie właściwych organów poprzez dostarczanie analizy strategicznej i analizy operacyjnej;

4. pełnienie roli Europejskiego Centrum Doskonałości w zakresie powyższych zadań $^{18}$.

Portal zawiera listę linków do monitorowanych stron internetowych, oświadczeń organizacji terrorystycznych oraz szczegóły dotyczące innych ekspertów

${ }^{17}$ J. Kaczmarek, Problemy współczesnego świata. Terroryzm i konflikty zbrojne a fundamentalizm islamski, Wrocław 1999, s. 20.

${ }_{18}$ Portal Departamentu Sprawiedliwości USA, http://www.justice.gov/ag/manualpart1_1.pdf [dostęp: 9.01.2018]. 
sprawdzających sieć w krajach UE, w tym ich kompetencje językowe i wiedzę techniczną. Niektóre państwa członkowskie - kierowane przez Niemcy - obecnie dzielą zadanie analizy działu medialnego al-Kaidy jako - Sahab według ambasadorów UE.

Ponadto specjalna Rada Europejska z dnia 23 kwietnia 2015 r. w sprawie sytuacji migracyjnej na Morzu Śródziemnym stanowiąca część politycznego kierunku nadanego agencjom UE oficjalnie wezwała Europol i IRU UE do rozszerzenia działalności w zakresie monitorowania Open Source i Internetu. Konieczne było monitorowanie i analiza nielegalnych sieci przemytu imigrantów poprzez wykrywanie i żądanie usunięcia treści internetowych wykorzystywanych przez handlarzy do przyciągania migrantów i uchodźców.

Niektóre materiały powinny być szczególnie chronione ze względu na skutki, które w niewłaściwych organach mogą wywołać. Przykładem podręcznika, który jest jednocześnie narzędziem szkolenia, był tzw. Manchester Manual (Podręcznik $z$ Manchesteru). Podręcznik, który został przygotowany dla ekstremistów islamistycznych, zawierał treści, które pomagały w tym, aby samodzielnie dokonać aktów terrorystycznych, w tym tych samobójczych. Publikacja została przypadkowo znaleziona przez służby w trakcie przeszukania jednej z kryjówek Al-Kaidy w Wielkiej Brytanii. Nigdy nie uzyskano informacji, w ilu egzemplarzach publikacja została wydana. Co więcej, dalej nie doprecyzowana jest wiadomość, do ilu osób dotarła i czy w dalszej perspektywie będzie wykorzystywana - chociaż dogłębna analiza pozwoliła na zweryfikowanie i zabezpieczenie niebezpiecznych treści ${ }^{19}$. Poniżej zostanie zamieszczony fragment publikacji, część z prezentowanych niżej danych można znaleźć na stronach rządowych, przy czym w sposób priorytetowy zadbano o usunięcie nieetycznych i zagrażających treści. Każdy przejaw aprobaty w stosunku do danych treści stanowiłby inspirację dla kolejnych osób. Niepokojący jest już sam spis treści i skrótowe opisy wyróżnionych podrozdziałów wykazanych jako lekcje. Zawartość podręcznika wygląda w następujący sposób:

1. Wprowadzenie.

2. Lekcja pierwsza: Ogólne zasady.

3. Lekcja druga: Niezbędne kwalifikacje i cechy członka organizacji.

4. Lekcja trzecia: Podrabianie pieniędzy i fałszowanie dokumentów.

5. Lekcja czwarta: Organizacja baz wojskowych. Mieszkania - schronienia.

6. Lekcja piąta: Środki komunikacji i transportu.

7. Lekcja szósta: Trening.

8. Lekcja siódma: Broń - sposoby zakupu i transportu.

9. Lekcja ósma: Bezpieczeństwo osobowe.

${ }^{19}$ Ibidem. 
10. Lekcja dziewiąta: Plan bezpieczeństwa.

11. Lekcja dziesiąta: Definicja operacji specjalnych.

12. Lekcja jedenasta: Szpiegostwo cz. 1 - Zbieranie informacji ze źródeł otwartych.

13. Lekcja dwunasta: Szpiegostwo cz. 2 - Zbieranie informacji metodami operacyjnymi.

14. Lekcja trzynasta: Szyfry i kody.

15. Lekcja czternasta: Porwanie i zabójstwa z użyciem broni długiej i krótkiej.

16. Lekcja piętnasta: Materialy wybuchowe.

17. Lekcja szesnasta: Zabójstwa z użyciem trucizny i broni białej.

18. Lekcja siedemnasta: Metody tortur.

19. Lekcja osiemnasta: Więzienia i miejsca zatrzymań.

Niewątpliwie, niniejszy podręcznik stał się inspiracją dla wielu osób, które zdecydowały się na zamachy terrorystyczne. W publikacji zostały zamieszczone treści dotyczące zasad, kwalifikacji, organizacji, metod pracy czy środków komunikacji i transportu. Kwestią, która jest najbardziej drastyczna, może być to, że w publikacji opisane są elementy związane $z$ treningiem, bronią, ale także metodami tortur czy zabójstw. Bez tego typu informacji trudne jest uzyskanie optymalnego pomysłu na wykorzystanie go w praktyce. Wskazówki mogą inspirować do szukania coraz to nowych faktów i poszerzenia dotychczasowej kwerendy.

Terroryzm jest związany $\mathrm{z}$ aktem przestępczym, często symbolicznym, który ma za zadanie wpłynięcie na opinię publiczną. Europejska definicja terroryzmu została sformułowana w Decyzji Ramowej Rady Unii Europejskiej z 13 czerwca 2002 roku o zwalczaniu terroryzmu. Decyzja ta zawiera szereg działań zaliczanych jako czyny terrorystyczne, w tym atak na życie osoby mogący powodować śmierć, atak na nietykalność osobistą osoby, porwanie lub wzięcie zakładnika. Kolejną kwestią, którą można wyróżnić, jest spowodowanie znaczących zniszczeń własności administracji państwowej, własności rządowej, systemu transportowego, infrastruktury, systemu informacyjnego, publicznej lub prywatnej własności. Aktem przestępczym jest także zajęcie statku, statku powietrznego lub innego środka transportu publicznego i środka transportu towarów oraz produkcja, nabywanie, posiadanie, transport lub użycie broni, materiałów jądrowych, materiałów wybuchowych, broni chemicznej, biologicznej. Dodatkowo niezgodne z prawem jest uwalnianie niebezpiecznych substancji powodujących pożar lub eksplozję, zakłócanie lub przerywanie dostaw energii elektrycznej, wody i innych zasobów naturalnych. Szkodliwa społecznie jest także groźba popełnienia jakiegokolwiek z wyżej wymienionych czynów. Aktem terrorystycznym jest także poważne zastraszanie społeczeństwa, bezprawne zmuszanie rządu lub organizacji międzynarodowych do podjęcia lub zaniechania jakiegoś działania, a także destabilizowanie 
lub zniszczenie podstawowych politycznych, ekonomicznych, konstytucyjnych lub społecznych struktur kraju i działania, które mogą powodować poważne szkody dla kraju lub organizacji międzynarodowej ${ }^{20}$.

\section{Podsumowanie}

Media i Internet są jednym z największych osiągnięć zachodniego kręgu cywilizacyjnego, a zarazem stanowią apogeum pewnego etapu rozwojowego. Warto zaznaczyć, że instytucje, państwa nie pozostają bierne w walce $\mathrm{z}$ terroryzmem - ważnym programem jest realizowany przez Unię Europejską program Check the Web - to międzynarodowa platforma współpracy europejskich służb policyjnych mających na celu ochronę i zwiększenie bezpieczeństwa ${ }^{21}$. Konieczne jest to, aby znaleźć kolejne możliwości, by chronić społeczeństwo przed negatywnymi skutkami dostępu do sieci. Niewiele zjawisk stanowi tak ogromne zagrożenie dla życia i zdrowia człowieka jak przestępczość zorganizowana, a nade wszystko - terroryzm. Chociaż zjawisko terroryzmu nie jest niczym nowym, to jednak współcześnie, przybiera ono nieznane wcześniej oblicza, kształtując jednocześnie innowacyjne, niespotykane dotąd formy. Wśród czynników postrzeganych jako emblemat dzisiejszej przestępczości zorganizowanej wymienia się determinację terrorystów, brak poszanowania dla własnego i cudzego życia, a w szczególności fakt, iż uderza on w ludność cywilną, wykorzystując za każdym razem element zaskoczenia. Począwszy od 11 września 2001 roku, a więc od zamachu na World Trade Center, zagadnienie terroryzmu coraz częściej gości w dyskursie publicznym i naukowym. Jest to pokłosie co najmniej dwóch czynników. Za pierwszy z nich uznać można niewątpliwie ogromny udział środków masowego przekazu w dostarczaniu aktualnych informacji o akcjach i działaniach terrorystów. Drugi natomiast ma charakter bardziej praktyczny; skala i rozmiar zjawiska powodują, że mamy do czynienia z problemem globalnym. Zgodnie z dostępnymi informacjami terroryści wykorzystują Internet nie tylko jako środek do komunikowania i szerzenia szeroko rozumianej propagandy, ale także do radykalizacji, rekrutowania oraz szkolenia terrorystów, którzy będą w stanie zabijać i wspierać organizacje zmierzające do niszczenia struktur społecznych ${ }^{22}$. Terroryści mają za zadanie przeprowadzać konkretne akcje, przestępstwa i przekazywać informacje, które stanowią niebezpieczeństwo dla innych osób.

\footnotetext{
${ }^{20}$ Decyzja Ramowa Rady Unii Europejskiej z dnia 13 czerwca 2002 roku, art. 1. (2002/475/JHA).

${ }^{21} \mathrm{https} / / /$ euobserver.com/justice/24162 [dostęp: 10.01.2018].

${ }^{22}$ B. Hołyst, Suicydologia..., dz. cyt., s. 105-220.
} 


\section{BIBLIOGRAFIA}

Cekiera Cz., Zapobieganie samobójstwom. Poradnik dla nauczycieli i innych pracowników szkoły, Genewa-Warszawa 2003.

Komender J., Zapobieganie próbom samobójczym podejmowanym przez dzieci i młodzież, [w:] Samobójstwo, red. B. Hołyst, M. Staniaszek, Warszawa-Łódź 1995.

Dymek-Balcerek K., Patologia społeczna wśród dzieci i młodzieży - rzeczywistość laty dziewięćdziesiątych, Radom 1999.

Hołyst B., Bezpieczeństwo jednostki, Warszawa 2014.

Hołyst B., Suicydologia, Warszawa 2012.

Hołyst B., Wiktymologia, Warszawa 2011.

Kwiatkowska G., Siudem A., Człowiek w środowisku pracy, Lublin 2011.

Pływaczewski E.W., Guzik-Makaruk E.M., Dajnowicz D., Działania Wydziału Prawa Uniwersytetu $w$ Białymstoku na rzecz przeciwdziałania wykluczenia społecznemu, [w:] Wybrane prawne kryminologiczne i medyczne aspekty wykluczenia społecznego, red. E.M. Guzik-Makaruk, E.W. Pływaczewski, Białystok 2016.

Susułowska M., Sztompka P., Próba wyjaśnienia młodzieżowych zamachów samobójczych, „Psychologia Wychowawcza” 1987, nr 5.

Ringel E., Gdy życie traci sens. Rozważania o samobójstwie, Szczecin 1987.

Jarosz M., Samobójstwa, Warszawa 1997.

Van Orden K.A. i in., The interpersonaltheory of suicide, „Psychological Review” 2010, t. 117.

Martin R.M., Should we try to prezent suicide?, [w:] Proceedings Communications, Ottawa 1979.

Kaczmarek J., Problemy współczesnego świata. Terroryzm i konflikty zbrojne a fundamentalizm islamski, Wrocław 1999.

\section{Netografia:}

http://www.justice.gov/ag/manualpart1_1.pdf [dostęp: 9.01.2018].

https://www.europol.europa.eu/publications-documents/eu-internet-referral-unit-year-one-report-highlights [dostęp: 12.01.2018].

https://euobserver.com/justice/24162 [dostęp: 10.01.2018].

http://suicydologia.org/ [dostęp: 10.01.2018]. 